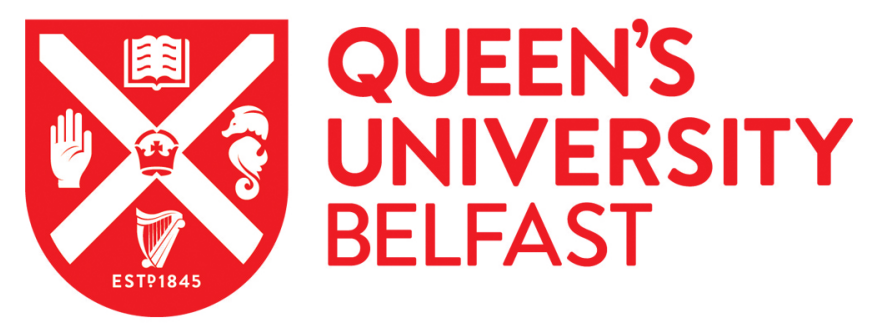

\title{
Stem cells applications in bone and tooth repair and regeneration: new insights, tools, and hopes
}

Abdel Meguid, E., Ke, Y., Ji, J., \& El-Hashash, A. H. (2018). Stem cells applications in bone and tooth repair and regeneration: new insights, tools, and hopes. Journal of Cellular Physiology, 233(3), 1825-1835.

https://doi.org/10.1002/jcp.25940

Published in:

Journal of Cellular Physiology

Document Version:

Peer reviewed version

Queen's University Belfast - Research Portal:

Link to publication record in Queen's University Belfast Research Portal

Publisher rights

Copyright Wiley 2017.

This work is made available online in accordance with the publisher's policies. Please refer to any applicable terms of use of the publisher.

\section{General rights}

Copyright for the publications made accessible via the Queen's University Belfast Research Portal is retained by the author(s) and / or other copyright owners and it is a condition of accessing these publications that users recognise and abide by the legal requirements associated with these rights.

Take down policy

The Research Portal is Queen's institutional repository that provides access to Queen's research output. Every effort has been made to ensure that content in the Research Portal does not infringe any person's rights, or applicable UK laws. If you discover content in the Research Portal that you believe breaches copyright or violates any law, please contact openaccess@qub.ac.uk. 


\title{
MINI-REVIEW
}

\section{Stem Cells Applications In Bone And Tooth Repair And Regeneration:}

\author{
New Insights, Tools And Hopes ${ }^{\dagger}$
}

\author{
Eiman Abdel Meguid ${ }^{1}$, Yuehai $\mathrm{Ke}^{2}$, Junfeng $\mathrm{Ji}^{2}$ and Ahmed HK El-Hashash ${ }^{3^{*}}$ \\ ${ }^{1}$ Centre for Biomedical Sciences Education, School of Medicine, Dentistry and Biomedical Sciences Queen's \\ University Belfast, Belfast, Ireland, UK, ${ }^{2}$ Stem Cell and Regenerative Medicine \& Molecular Medicine \\ Research Centre, School of Basic Medical Sciences and School of Medicine, Zhejiang University, \\ Hangzhou, Zhejiang, China, ${ }^{3}$ The University of Edinburgh, Edinburgh Medical School-Zhejiang \\ International Campus, UoE-ZJ. \\ *Corresponding author: \\ Professor Ahmed El-Hashash, $\mathrm{PhD}$ \\ (Office \# 429, clo Ms. Ajda Yang) \\ The University of Edinburgh \\ Edinburgh Medical School- \\ Zhejiang International Campus, \\ (ZJU), Arts \& Science Building, \\ Haining, Zhejiang 314400 \\ Tel: $+86-057187572820$ \\ Fax: +86-571-87572815 \\ Email: hashash05@yahoo.co.uk \\ Short Title: Stem Cells In Bone Repair And Regeneration \\ Key Word: Stem Cells, Bone, Tooth, Tissue Repair, Regeneration \& Engineering \\ Conflicts of Interest: None of the authors has a conflict of interest to disclose \\ Conflicts of Interest: None of the authors has a conflict of interest to disclose.
}

${ }^{\dagger}$ This article has been accepted for publication and undergone full peer review but has not been through the copyediting, typesetting, pagination and proofreading process, which may lead to differences between this version and the Version of Record. Please cite this article as doi: [10.1002/jcp.25940] 


\begin{abstract}
The exploration of stem and progenitor cells holds promise for advancing our understanding of the biology of tissue repair and regeneration mechanisms after injury. This will also help in the future use of stem cell therapy for the development of regenerative medicine approaches for the treatment of different tissue-specie defects or disorders such as bone, cartilages and tooth defects or disorders. Bone is a specialized connective tissue, with mineralized extracellular components that provide bones with both strength and rigidity, and thus enable bones to function in body mechanical supports and necessary locomotion process. New insights have been added to the use of different types of stem cells in bone and tooth defects over the last few years. In this concise review, we briefly describe bone structure as well as summarize recent research progress and accumulated information regarding the osteogenic differentiation of stem cells, as well as stem cell contributions to bone repair/regeneration, bone defects or disorders and both restoration and regeneration of bones and cartilages. We also discuss advances in the osteogenic differentiation and bone regeneration of dental and periodontal stem cells as well as in stem cell contributions to dentine regeneration and tooth engineering. This article is protected by copyright. All rights reserved
\end{abstract}




\section{Introduction}

Stem cells can continuously produce unaltered daughters and could generate cells with different and more restricted properties. Stem cells can divide either symmetrically (allowing the increase of stem cell number) or asymmetrically. Asymmetric divisions keep the number of stem cells unaltered and are responsible for the generation of cells with different properties. These cells can either multiply (progenitors or transit amplifying cells) or be committed to terminal differentiation (Morrison and Kimble, 2006; Berika et al., 2014; Elshahawy et al., 2016; El-Hashash, 2015).

Progenitors and transit amplifying cells have a limited lifespan and therefore can only reconstitute a tissue for a short period of time when transplanted. In contrast, stem cells are self-renewing and thus can generate any tissue for a lifetime. This is a key property for a successful therapy. The capacity to expand stem cells in culture is an indispensable step for regenerative medicine, and a considerable effort has been made to evaluate the consequences of the cultivation on stem cell behavior. Scientists rely on indirect properties to identify stem cells such as the expression of a repertoire of surface proteins, slow cell cycle, clonogenicity, or an undifferentiated state. The evaluation of self-renewal is the ultimate way to show "stemness", which relies on the isolation and transplantation of a putative stem cell (clonal analysis) followed by its serial transplantation and long-term reconstitution of a tissue (He et al., 2009).

Recently, stem cells have been used extensively in many medical disciplines for the repair and/ or regeneration of defective tissues and organs (e.g. bone, ligament, heart). New therapeutic approaches are largely inspired and based on our knowledge of embryonic development. The goal of regenerative medicine is to stepwise re-create in vitro all the mechanisms and processes that nature uses during initiation and morphogenesis of a given organ. In this context, stem cell research offers an amazing and seductive potential for body homeostasis, repair, regeneration and pathology. The possibility of manipulating stem cells in situ using specific signalling molecules or by expanding them ex vivo is an exciting outcome of basic research. Hence, regenerative medicine has become a fashionable field and the isolation and manipulation of embryonic and adult (or post-natal) stem cells for the creation of new functional organs that will replace the missing or defective organs constitutes an enormous challenge. Adult stem cells (ASC), which possess a restricted potential of differentiation, can easily be isolated from a patient and after in vitro amplification 
and/or differentiation could be re-injected to the same patient thus avoiding immune rejection, as is the case for allografts or xenografts. However, the knowledge in stem cell technology is increasing quickly in all medical disciplines and dictates the need for new strategic approaches in all fields, including reparative dentistry. Stem cells have a great hope for various tissue repair, regeneration and engineering as well as for treatments of different human diseases (Mimeault and Batra, 2006; Caplan, 2007).

\section{Structure of the bone}

The bone is a rigid organ that support and protect the various organs of the body, produces red and white blood cells, store minerals and enable mobility as well as support for the body. Bone is a specialized type of dense connective tissue as its extracellular components is mineralized to provide strength and rigidity. This makes it capable to fulfil its major role in supporting the whole body mechanically and in locomotion (Weatherholt et al., 2012). It gives attachment to skeletal muscles, protects organs and plays a significant role in mineral homeostasis, particularly calcium and phosphorus (de Baat et al., 2005; Bayliss et al., 2012).

Osteon is regarded as the building unit of a bone. It consists of concentric lamellae around a Haversian canal. Osteons are connected to each other and to the periosteum by oblique channels called volkmann's canals. The space between osteons is occupied by interstitial lamellae which are remnants of osteons that were partially resorbed during the process of bone remodelling (Bayliss et al., 2012).

There are two types of osseous tissue; the solid cortical compact bone tissue and the cancellous bone or spongy bone. The solid cortical compact bone tissue is the hard-outer layer of the bone. It is one of the two types of osseous tissue that form bones. It forms $80 \%$ of osseous mass; provide levers for movements and store and release chemical elements mainly calcium (Marieb, 1998). The cancellous bone, also known as trabecular or spongy bone, is found at the ends of long bones, as well as in the pelvic bones, ribs, skull, and the vertebrae. It has many pores covering 50-90 \% of its volume. These pores give it spongy honeycomb-like appearance. Cancellous bone is highly vascular and frequently contains red bone marrow where haematopoiesis occurs (Marieb, 1998; Weatherholt et al., 2012; Gdyczynski, 2014). 
The periosteum that lines surfaces of bone is divided into two layers; an outer fibrous layer and an inner cambium or osteogenic layer. The fibrous layer contains fibroblasts while the cambium layer is in contact with the bone. It contains the progenitor cells, which develop into osteoblasts (Weatherholt et al., 2012).

\section{Matrix of the bone}

It is the intercellular substance of bone tissue. It consists of collagen fibres, ground substance and inorganic bone salts. Type I collagen provides bone with its flexibility and is the main component of its organic portion. The remainder is made up of osteoids, proteoglycans and non-collagenous proteins including fibronectin, osteocalcin, osteonectin, thrombospondin and matrix-gla-protein. Fibronectin is abundant and regulates osteoblast differentiation while osteonectin regulates mineralization. Thrombospondin inhibits bone cell precursors while osteocalcin binds calcium. Lastly, matrix-gla-protein prevents mineralization. On the other hand, the inorganic portion of the bone matrix acts as an ion reservoir (Weatherholt et al., 2012).

The matrix is mostly made up of a composite material incorporating the inorganic minerals including calcium phosphate in the chemical arrangement termed calcium hydroxylapatite [Ca10 (PO4)6 (OH)2], which is the bone mineral that gives bones their rigidity, fluoride, sodium, potassium, and magnesium in addition to collagen which is an elastic protein that improves its fracture resistance. Bone stiffness and flexibility are provided by its collagen and minerals (Weatherholt et al., 2012; Bayliss et al., 2014).

\section{Cellular elements of the bone}

The major cell types of bone are osteoblasts (OBs), osteoclasts (OCs), and osteocytes (Kartsogiannis, 2004). The haematopoietic stem cells (HSCs) and mesenchymal stem cells (MSCs) give rise to the osteoclasts that modulate bone resorption and osteoblasts that mediate bone formation. Osteoblasts are necessary for bone reconstruction (Weatherholt et al., 2012). The human skeleton integrity and strength are dependent on a delicate balance between bone formation by osteoblasts and bone resorption by osteoclasts. This balance is affected by various types of genetic and mechanical alterations. Degenerative skeletal diseases, including osteoporosis, become increasingly prevalent during human life. Osteoporosis, for example, reflects a relative preponderance of osteoclast activity and bone resorption exceeds bone formation (Weatherholt et al., 2012). 
MSCs are defined as self-renewing and multipotent cells capable of differentiating into multiple cell types including osteocytes and chondrocytes. MSCs were originally isolated from the bone marrow stroma but they have recently been identified also in other tissues such as fat, epidermis and cord blood. It remains in a non-proliferative, quiescent state until stimulated by the signals triggered by tissue renewal, damage and remodelling process. Development of MSCs is associated with mesodermal sclerotome condensation that subsequently differentiates into other cell types for bone remodelling. Stimulatory factors are needed for MSCs. They are derived from osteoblastogenesis such as the bone morphogenetic protein (BMPs), which act as the starting inducer of osteoblastogenesis. Seven BMPs were discovered. Of these, six belong to the Transforming growth factor beta superfamily of proteins (TGF $\beta$ ). MSCs which are derived from bone marrow fat plays a major role in accelerating bone fracture tackling as they are the precursors of osteoblasts (Quarto et al., 2001). Bone marrow contains both hematopoietic stem cells and MSCs. Bone marrow transplantation has been advocated as a potential future therapeutic modality for osteogenesis imperfecta (Horwitz et al., 2002).

\section{Remodeling of the bone}

It is a lifelong skeletal dynamic process which occurs over several weeks and is performed by clusters of bone-resorbing osteoclasts and bone-forming osteoblasts arranged within the temporary anatomical structures known as the Basic Multicellular Units (BMU), which consist of osteoclasts, osteoblasts, and osteocytes (Kular et al., 2012). In the BMU, the amount of bone destroyed by osteoclasts is equal to the amount of bone formed by osteoblasts (Lips et al., 1978). Mature bone tissue is removed from the skeleton (a process called bone resorption) and new bone tissue is formed (a process called ossification). These processes control the reshaping or replacement of bone following fractures and micro-damage which occurs during normal activity. An imbalance in the regulation of bone remodeling's two sub-processes, bone resorption and bone formation, results in many metabolic bone diseases such as osteoporosis (Raggatt et al., 2010). Moreover, bone remodelling is a life-dominant process, where cortical and trabecular bone is rebuilt, and it plays a crucial role in bone mass balance and mineral homeostasis (Tolar et al., 2004). Intriguingly, 
non-BMU cells, including T-cells, B-cells, and nerve cells also play an important role in bone remodelling (Gillespie et al., 2007; Horowitz and Lorenzo, 2007; Elefteriou, 2008).

The remodelling mechanism of the bone includes initiation phase, reversal phase and termination phase. Initiation phase is the first process in the remodelling cycle, in which osteoclast precursors are recruited and differentiated into mature osteoclasts to maintain bone resorption. Reversal phase is associated with bone resorption inhibition and the osteoblasts are recruited and started to be differentiated. Termination phase is the final step in the cycle which occurs when an equal quantity of resorbed bone has been replaced, the remodelling cycle concludes (Kular et al., 2012, Raggatt and Partridge, 2010). Finally, there is a connected network among each of those cells and the osteocytes (Kular et al., 2012). This phase is based on a mechanism that requires a key mediator called receptor activator of nuclear factor kappa-B ligand (RANKL), which is essentially required for osteoclastogenesis (Dougall et al., 1999; Palmqvist et al., 2002). Ligandreceptor interaction of RANKL-RANK triggers the termination phase by promoting osteoclast precursor fusion and colony stimulating factor (CSF-1) (Arai et al., 1999; Parfitt et al., 2002; Lee et al., 2006; Tatsumi et al., 2007). The BMU that comprises the remodelling process in the bone involves multiple Intercellular communication pathways, as summarized in Figure (1).

Much of bone turnover markers, that quantify bone resorption, are collagen breakdown products, telopeptides, and pyridinoline rings (Brown et al., 2009). Deoxypyridinoline (DPD) is released into the circulation after resorption of bone matrix and thereafter is excreted in urine (Garnero and Delmas, 2004). BMU at the initiation, reversal (transition) and termination phases of bone remodelling cycle.

\section{Osteogenic differentiation of stem cells}

Identification and isolation of osteoprogenitor cells and other stem cell types that are capable of osteochondral differentiation to inform both bone repair and regeneration is a subject of several recent studies. For instance, human adipose tissue-derived mesenchymal stem cells (hAMSCs) are capable to both differentiate into osteoblasts and produce bone matrix of bone marrow derived stem cells (Tognarini et al., 2008). Moreover, Olivares-Navarrete et al. (2010) have shown that human mesenchymal stem cells (MSCs) can differentiate into osteoblasts when growing on Titanium surfaces with microscale roughness even if the 
culture medium lacks osteogenic components. It has also been shown that nanostructured Titanium alloys (Ti6Al4V and Ti13Nb13Zr) can sustain the proliferation, growth and adhesion of hAMSCs. These alloys also promote the osteogenic differentiation of hAMSCs (Marini et al., 2015). In addition, a recent study by Gothard and co-workers has shown that regionally-derived cell populations and skeletal stem cells from human fetal femora exhibit specific osteochondral and multi-lineage differentiation capacity both ex vivo and in culture (Gothard et al., 2015).

Several factors have been reported to regulate stem cell function and differentiation into osteoblasts. For instance, Hox transcription factors regulate skeletal patterning during embryogenesis, and are expressed in adult bone tissues. They are expressed in specific and restricted domains and control the morphology of certain vertebral and long bone elements (Rux and Wellik, 2017). Progenitor-enriched populations of mesenchymal stem/ stromal cells (MSCs) express Hox genes in the adult skeleton, in which these genes play an important role in both skeletal regeneration and the fracture healing process (reviewed by Rux and Wellik, 2017).

Most recently, members of zinc-finger transcription factors, Snail and Slug, have been reported to regulate both the behavior and function of bone marrow-derived mesenchymal stem cells (MSCs) as well as bone formation (Tang and Weiss, 2017). Snail and Slug are zinc-finger transcription factors are well-known regulators of the epithelial-mesenchymal transition (EMT) programs during both normal development and disease progression. Tang and Weiss (2017) have recently reported that both Snail/Slug and the two cotranscriptional effectors of the Hippo pathway, YAP/TAZ, cooperatively interact. This interaction is important for the control of self-renewal and differentiation properties of bone marrow-derived mesenchymal stem cells, which is a critical cell population in both bone development and morphogenesis (Tang and Weiss, 2017).

Growth factors and extracellular matrix proteins also play important roles in the osteogenic differentiation of stem cells. For instance, a recent research by Wang Y et al. (2016) has investigated the positive and reciprocal effect of TGF- $\beta 3$ on BMP-2 growth factor in promoting osteogenic differentiation, based on an early study by (Haschtmann et al., 2012) that showed that co-delivery of BMP-2 and TGF- $\beta 3$ is more 
effective than single gene-transfection in promoting ossification of the annulus fibrosus. Wang and coworkers simultaneously expressed BMP-2 and TGF- $\beta 3$ genes in rabbit bone marrow-derived mesenchymal stem cells. Then, they measured the expression status of both BMP-2 and TGF- $\beta 3$ in culture to elucidate whether these growth factors can be synergistically expressed in vivo. This study has demonstrated a synergistic effect of the overexpression of BMP-2 and TGF- $\beta 3$ on osteogenic differentiation of bone marrow mesenchymal stem cells Wang et al. (2016). In addition, Polini et al. (2014) have developed a strategy, based on in situdelivery of growth factor-inspired peptides through their immobilization onto Hydroxyapatite (HA), which is the principal component of bone mineral, surfaces. This study found that stable biofunctionalization of HA surfaces by HA-binding/osteogenic modular peptides induces osteogenic differentiation of mesenchymal stem cells (Polini et al., 2014).

\section{Stem cell contributions to bone repair and regeneration}

Several reports have shown that mesenchymal stem cells (MSC) that are derived from periosteum and bone marrow are involved in fracture repair. They have also shown that the impairment of bone regeneration is probably due to a damage of the surrounding skeletal muscle (reviewed in Owston et al., 2016). For example, a recent study from Cao's laboratory (Islam et al., 2016) has shown that fluorescently labelled human embryonic stem cells-derived osteoprogenitors (hESC-OPs) are able to maintain both their GFP expression for the long term and their potential for osteogenic differentiation in culture. This will help in the future application of these fluorescently labelled hESC-OPs in the noninvasive assessment of bone regeneration and therapeutic efficacy.

Bone marrow stem cells can grow in vitro, and cultured bone marrow osteoprogenitors can be used for bone regeneration after seeding on an appropriate scaffold material, as shown in Figure (2). Most recently, Chen et al. (2017) have shown evidences of a successful angiogenic and osteogenic regeneration in rats via calcium phosphate scaffold (CPC) and endothelial cell co-culture with human bone marrow MSCs (hBMSCs), human umbilical cord MSCs (hUCMSCs), induced pluripotent stem cells (hiPSC-MSCs) and embryonic stem cells (hESC-MSCs). Thus, co-cultures of hUVECs with hUCMSCs, hiPSC-MSCs, hESCMSCs and hBMSCs delivered via CPC scaffold have achieved excellent osteogenic and angiogenic capabilities in vivo (Chen et al., 2017). These co-culture constructs will provide promising solutions for bone 
reconstruction with improved angiogenesis for both orthopedic and craniofacial applications. Similarly, a recent study has shown a successful bone regeneration in minipigs via calcium phosphate cement scaffold delivering autologous bone marrow mesenchymal stem cells (BMSCs) and autologous platelet-rich plasma (Qiu et al., 2017). Another approach that has also been reported to be successful for prompting bone regeneration is the incorporation of a bone marrow-derived mesenchymal stem cell (BMSC) sheet into the platelet-rich plasma (PRP) gel/calcium phosphate particles, which will offer effective therapeutic strategies for promoting the clinical repair of bone defects (Qi et al., 2015).

Furthermore, a most recent research by Joo et al. has compared bone regeneration using allogeneic cancellous bone granule scaffolds loaded with autologous bone marrow-derived mesenchymal stem cells (BM-MSC) with or without autologous platelet-rich plasma (PRP), and showed a similar progression of new bone formation and maturation (Joo et al., 2017). Furthermore, several recent reports have highlighted the advantages of adipose-derived stem cells (ASCs) over other stem cells that are derived from bone marrow. These advantages include a higher number of stem cell progenitors from an equivalent amount of tissue harvested, a less invasive procedure of cell harvesting, a significate increase of both proliferation and differentiation capacities, as well as better osteogenic/angiogenic properties in vivo (Dufrane, 2017).

\section{Stem cell contributions to bone defects and both restoration and regeneration of bones and cartilages}

The cranial and facial bone defects are complicated, particularly because of the difficulty of finding an appropriate autologous bone transplant for them. Current treatments of these defects using stem cells have been successful, and their safety have been proved using preclinical experiments. For instance, several reports have shown the effective functions of adipose-derived stem cells in the experimental treatment of different types of bone defects (reviewed by Seppänen and Miettinen, 2014).

Bone marrow-derived mesenchymal stem cells (BMSC) are also important cell population for bone tissue repair, engineering and regeneration. Addition of recombinant human bone morphogenetic protein (rhBMP- 
2) to a silica-coated calcium hydroxyapatite (HASi)- rabbit BMSC (rBMSC) construct could promote bone healing and regeneration in a large critical-size-defect in rabbits (Maiti et al., 2016).

Umbilical cord mesenchymal stem cells (UCMSCs) and amniotic fluid-derived stem cells (AFSCs) are also attractive cell populations for bone repair/regeneration as well as promising candidates for cell therapy and tissue engineering. In a recent study from Liu's laboratory, UCMSCs were transplanted into the bone defect peri-implant, and were capable to promote bone repair/regeneration and new bone formation (Hao et al., 2014). In contrast, both the experimental and preclinical applications of AFSCs in bone repair/regeneration, including maxillofacial bone tissue engineering, are still limited. However, a recent study by Wang and others (Wang et al., 2017) has proposed an AFSCs-based bone tissue engineering strategy for congenital alveolar cleft restoration. This study has evaluated the regenerative properties of AFSCs in restoration of alveolar bone defect, and provided evidences of the feasibility of an AFSCs-based alveolar bone tissue engineering strategy for alveolar defect restoration (Wang et al., 2017).

Similarly, stem cells are a highly promising tool for new developments in cartilage tissue regeneration. Both ex vivo expanded chondrocytes and BMSC are currently extensively used in the regeneration of damaged cartilages. BMSC are the most used stem cell source in the engineering and repair of cartilage tissues (Georgi et al., 2014; Tritz-Schiavi et al., 2010). However, the use of autologous BMSC have certain limits, including possible damage of donor site, painful collection methods, low number of available BMSC, and the decrease of both their proliferation capacity and differentiation potential with age (Pittenger et al., 1999; Zaim et al., 2012; Fossett et al., 2012). To help with sorting out these difficulties, Reppel and his colleagues have attempted to identify alternative sources of MSC in cartilage tissue repair/engineering (Reppel et al., 2015). They have evaluated the chondrogenic potential of mesenchymal stromal/stem cells from Wharton's jelly (WJ-MSC), which were embedded in alginate/hyaluronic acid (Alg/HA) hydrogel, compared to the potential of BMSC. This study has found that WJ-MSC, embedded in a three-dimensional environment, were able to adapt to their environment and express specific cartilage-related genes and matrix proteins and, therefore, represent a promising alternative stem cell source for cartilage tissue engineering (Reppel et al., 2015). Another new replacement cell source for cartilage repair is human induced pluripotent stem cells (hiPSCs), mostly because of their multipotency and unlimited self-renewal ability. Nam and others (2017) have mostly recently reported the characteristics of cartilage-like chondrogenic pellets generated from 
cord blood mononuclear cell-derived hiPSCs (CBMC-hiPSCs), suggesting these cells as a potential cell source for cartilage repair and regeneration.

\section{Osteogenic differentiation and bone regeneration of dental and periodontal stem cells}

Human periodontal ligament (PDL) represents a unique reservoir of stem cells because it contains a unique population of multipotent stem cells, which have the capacity to differentiate and form cells with diverse phenotypes (Mrozik et al., 2010). Moreover, Seo et al. (2004) have shown that periodontal ligament stem cells (PDLSCs) that are transplanted in nude mice, can form an ectopic cementum/ligament-like complex. Tissue regeneration mediated by human PDLSCs (Figure 3) represent a promising practical cell-based treatment for various periodontal diseases (Tamaki et al., 2013; Figure 3). In addition, a study from Meng's laboratory (Zhang et al., 2014) has aimed to investigate human PDLSCs for their stem cell characteristics via analysis of cell surface marker expression, colony forming unit efficiency, osteogenic differentiation and adipogenic differentiation, and compared to BMSCs. This study has suggested that BMSCs owned the stronger immunomodulation in local microenvironment via anti-inflammatory functions, compared to PDLSCs (Zhang et al., 2014). In addition, Chen et al. (2015) has used the indirect co-culture approach to elucidate the effects of PDLSCs on differentiation of osteoblast-like cells and osteoclast precursors in culture, and found that PDLSCs promote osteoblastic differentiation of osteoblast precursors and osteoclastic differentiation of osteoclast precursors.

Dental pulp stem cells (DPSCs) are derived from neural crest cells and represent one of the most widely used seed cells in the field bone tissue engineering/regeneration for several reasons, including their easily isolation, low immunogenicity, lack of ethical controversy and reduced rates of transplantation rejection (Pierdomenico et al., 2005; Huang et al., 2009; Sakai et al., 2012). DPSCs show MSC characteristics and can differentiate into many cell types, including odontoblasts, osteoblasts, chondrocytes. DPSCs are, therefore, capable of differentiation into bone cells, promoting both the regeneration and repair of alveolar bone defects (Huojia et al., 2015). de Mendonca et al. (2008) have transplanted human DPSC into large rat calvarial defects and found that they can differentiate into osteogenic cells without rejection of the graft. Moreover, dense collagen gel scaffolds seeded with rat DPSC (rDPSC) that were implanted in a rat critical-sized 
calvarial defect model have accelerated both osteogenic DPSC differentiation and craniofacial bone regeneration (Chamieh et al., 2016).

Other types of stem cells may also important in bone regeneration. A recent research by Szepesi et al. (Szepesi et al., 2016) has aimed to compare the properties of differentiated human MSCs from adult adipose tissue (AD-MSCs), Wharton's jelly of the umbilical cord (WJ-MSCs), and Periodontal ligament stem cells (PDLSCs) that were grown in culture. This study has also investigated the combined in vitro osteogenic and endothelial differentiation capacities of MSCs that were derived from Wharton's jelly, adipose tissue, and periodontal ligament, and found that MSCs that were isolated from periodontal ligament and adipose tissue are probably most appropriate for the generation vascularized bone graft Szepesi et al., 2016). Indeed, a recent experimental study in the dog has suggested adipose-derived stem cells as a tool for dental implant osseointegration (Bressan et al., 2015). Moreover, dental follicle (DF) stem cells have been shown to have a spontaneous tendency for osteogenic differentiation, and were suggested for bone regeneration (Lucaciu et al., 2015).

\section{Stem cell contributions to dentine regeneration and tooth engineering}

Tooth development results from sequential and reciprocal interactions between both the oral epithelium and the underlying neural crest-derived mesenchyme. The manipulation of stem cells is important for the generation of dental structures in the laboratory. This dental structure generation requires better understanding of the synergy of molecular and cellular events and mechanisms that are involved in the formation of various tooth-specific hard tissues, dentin and enamel.

Over the past decade, the dental field has benefited from recent findings in stem cell biology and tissue engineering that led to the elaboration of novel ideas and concepts for the regeneration of dental tissues or entire new teeth. Stem cell-based regenerative approaches are, therefore, extremely promising since they aim at the full restoration of lost or damaged tissues, ensuring thus their functionality. These therapeutic approaches are already applied with success in clinics for the regeneration of other organs and consist of manipulation of stem cells and their administration to patients. Stem cells have the potential to 
self-renew and to give rise to a variety of cell types that ensure tissue repair and regeneration throughout life (Miran et al., 2016).

Mammalian teeth contain mesenchymal stem cells (MSCs) that contribute to both tooth growth and repair, and are characterized by both their accessibility and clinical relevance that provide a valuable opportunity to test stem cell-based treatments for dental defects (Sharpe, 2016). These dental MSCs show similar features to bone marrow-derived MSCs in culture, such as expression of certain markers, and clonogenicity, as well as differentiation into cells that have the characteristics of chondrocytes, osteoblasts and adipocytes. Teeth and their support tissues provide both easily accessible source of MSCs and a tractable model system to investigate them in vivo properties and function. (Sharpe, 2016). Different types of MSCs have been extensively investigated for their capacity to form dentin in culture. In contrast, more studies are still needed for understanding the applications of epithelial stem cells in tooth regeneration, particularly because odontogenic potential resides in the oral epithelium and, therefore, epithelial stem cells are critical for tooth formation and production of enamel matrix.

Tooth regeneration through stem cell-based therapy is a promising treatment for tooth decay and loss. Human dental pulp stem cells (hDPSCs) have been widely identified as the stem cells with the most potential for tooth tissue regeneration. However, growing culture of hDPSCs in culture for tissue engineering is still a challenge because cells may differentiate poorly and/or proliferate slowly in vivo. Dynamic three-dimensional (3D) simulated microgravity (SMG) created using the rotary cell culture system is considered to an effective tool, which contributes to several cell functions. A recent study by Li et al. (2017) has used various histological and immunohistochemical examinations of Ki-67, dentin sialoprotein, type I collagen and DMP-1, and found that both the proliferation and odontogenic differentiation abilities of the hDPSCs that were prepared in the 3D SMG culture system were higher, compared with those prepared in the static culture system. These results suggested that dynamic 3D SMG abilities of hDPSCs in vivo (Li et al., 2017).

Stem cell therapy is currently considered as a potential strategy to regenerate the dentin-pulp complex, enabling the conservation and restoration of functional teeth, and both standardization and establishment of 
regulatory guidelines for stem cell therapy in clinical endodontics are a subject of intensive research. One of the key factors that induces subsets of dental pulp stem cells to form mobilized dental pulp stem cells (MDPSCs) is granulocyte-colony stimulating factor (G-CSF). It is well-established that good manufacturing practice is a prerequisite for both isolation and expansion of MDPSCs, which are enriched in stem cells that extensively express trophic factors with properties of high migration, proliferation, and antiapoptotic effects and endowed with regenerative potential. Nakashima and co-workers (2014) have found that autologous transplantation of MDPSCs with G-CSF in pulpectomized teeth in dogs augmented the regeneration of pulp tissue. In this research, the quality of clinical-grade MDPSCs was confirmed by the absence of karyotypic abnormalities and the lack of tumor formation after transplantation in immune-deficient mice. This study has confirmed the combinatorial trophic effects of MDPSCs and G-CSF on cell migration, immunosuppression, anti-apoptosis, and neurite outgrowth were in culture, as well as has established the preclinical safety, feasibility, and efficacy of pulp regeneration by MDPSCs and G-CSF (Nakashima et al., 2014).

Most recently, Qi et al. (2017) have demonstrated that the proliferation of hDPSCs was stimulated after delta-like homologue (DLK1) overexpression, which suppressed the odontoblastic differentiation of hDPSCs, probably through ERK signaling pathway. Both DLK1 and p-ERK1/2 were strongly expressed on the odontoblasts and dental pulp cells on the first maxillary molar, and

DLK1 expression levels increased after the odontoblastic induction of hDPSCs (Qi et al., 2017).

Dental pulp stem cells also play an important role in pulp revascularization. The pulp vascular system actively contributes to waste removal, nutrient supply, and both pulp inflammatory response and subsequent regeneration. Under hypoxic stress, dental pulp cells release proangiogenic factors such as vascular endothelial growth factor. Exogenous vascular endothelial growth factor has widely applied in tissue engineering (reviewed in Rombouts et al., 2017). It has been demonstrated that dental pulp stem cell secretome possesses angiogenic potential, which can contribute to the angiogenic process in different ways such as differentiating themselves into the endothelial lineage and guiding endothelial cells (Rombouts et al., 2017).

Progenitor stem cell niches also exist in the post-natal pulp, and have important functions in both dentine formation and wound healing. Progenitor stem cell niches have a multi-potentiality property and, therefore, 
can differentiate osteoblasts and chondrocytes in response to specific stimuli (Sloan and Waddington, 2009). They can also differentiate into odontoblasts and, therefore, are considered as a natural reparative mechanism. This can be triggered by an inflammation, injury or trauma that also affects their proliferation activities. For instance, inflammations in the dental regions have been found to associate with recruitment of tooth progenitor cells that migrate to the injury regions from their niches to stimulate the repairing mechanisms (Téclès et al., 2005). In addition, (Løvschall et al. (2005) have investigated stem cell niches in vivo by Notch expression increment followed by pulpal injury. These experiments added further niches to the perivascular ones (Løvschall et al., 2005).

\section{Dental pulp stem cells and age-related changes}

Aging is the progressive decline of physiological integrity that leads to age-related degenerative diseases. Dental pulp has several functions, including pulp cell activity involvement in dentin formation. Several changes have been reported during the aging process, including a progressive reduction of the pulpal chamber size, a progressive deposition of calcified masses in the root and coronal pulp, and fewer nerves, cells and blood vessels within the pulp, as well as an increase in the fibrous component (Pashley et al., 1994). In addition, both pulpal wound healing and cell regeneration are probably compromised with increasing age because of a sever reduction of potential stem/progenitor cell number in the dental pulp (Smith et al., 2005).

The causes of dental pulp aging are unclear. It is still not clear whether age-related changes are due to intrinsic factors that exit during cell aging or are induced through extrinsic factors of the somatic environment (Sethe et al., 2006). Development of aging-related molecules in pulp cells requires better understanding of cellular and molecular mechanisms that are responsible for tooth preservation and maintenance strategies.

Lee et al. (2013) have investigated human dental pulp cells (hDPCs), and found that replicative senescence, which is often thought to be synonymous with aging, of these cells was characterized by both senescenceassociated $\beta$-galactosidase activity and reactive oxygen species formation. This study has further shown that hDPCs exhibited altered expression of several chronic inflammatory molecules, including peroxisome proliferator activated receptor-gamma, vascular cell adhesion molecule-1, intracellular adhesion molecule-1, 
and heme oxygenase-1 and age-related molecules such as p53, p21, phosphorylated-extracellular signalregulated kinase, and c-myb. Furthermore, hDPCs decreased odontogenic markers such as dentin matrix-1 and osteogenic markers such as bone morphogenetic protein-2 and -7 , runt-related transcription factor-2, osteopontin, alkaline phosphatase activity, and mineralized nodule formation by replicative senescence (Lee et al., 2013).

Human DPSCs (hDPSCs) are characterized by their rejuvenated capacity that relies on its resident stem cells. Until most recently, identification of the underlying molecular mechanisms that control dental pulp stem cells senescence and aging was hindered, mostly because of the lack of proper senescence models. Zhai and his colleagues (Zhai et al., 2017) have recently identified these age-related phenotypic changes by augmented senescence-associated- $\beta$-galactosidase (SA- $\beta$-gal) staining, elevated G0/G1 cell cycle arrest, increased apoptosis, and declined proliferation and differentiation capacity, as well as reactive oxygen species levels. This study has also shown that dental pulp stem cells from young donors are more resistant to apoptosis and exhibit increased non-homologous end joining activity compared to old donors. They have also shown that induced dental pulp stem cells ageing is dependent on several factors and pathways such as genes associated with DNA damage and repair, mitochondrial dysfunction and increased reactive oxygen species levels (Zhai et al., 2017).

Another type of stem cells, mesenchymal stem cells derived from human dental pulp (DP-MSCs), are characterized by self-renewal and multi-lineage differentiation and play important functional roles in regenerative medicine. The safest approach in cellular transplantations is autologous transfer, as nonimmunogenic. However, the applications of this autologous transfer in regenerative medicine may be limited by age-related changes (Feng et al., 2014). Indeed, several studies have reported a decrease in the osteogenic differentiation potential of MSC and an increase of MSC adipogenic potential with age, which has been coined as the adipogenic switch (D'Ippolito et al., 1999; Bergman et al., 1996; Ross et al., 2000; Stolzing et al., 2008).

The age-related changes also influence mesenchymal stem cells (MSCs). The regenerative abilities of MSCs show an age-associated decline, probably due to several age-related changes in MSC number, intrinsic 
properties of MSCs and extrinsic factors of the extracellular environment (the stem cell niche). Until recently, variable methods of MSC isolation and variations in stem cell populations have hindered investigations of the effect of age on the efficacy of MSC transplantation on regeneration. However, a study by Iohara et al. (2014) has provided a better understanding of the mechanisms involved in the age-dependent decline in pulp regeneration that are attributed to a decrease in the regenerative potential of resident stem cells. This study has demonstrated that MDPSCs from aged dogs were efficiently enriched in stem cells, expressing trophic factors with high migration, proliferation, and anti-apoptotic effects as in MDPSCs from young dogs. This research has, however, shown that pulp regeneration was retarded 120 days after autologous transplantation of aged MDPSCs. In addition, they have found that isolated periodontal ligament stem cells (PDLSCs) from aged dogs, which are representative of migrating stem cells from outside of the tooth compartment to regenerate pulp tissue, show lower migration, proliferation and anti-apoptotic abilities (Iohara et al., 2014).

\section{Conclusions and future directions}

In conclusion, this review has shown that different stem cell types, including human MSCs, and hAMSCs can differentiate into bone cells. Identification and isolation of these stem cell types and osteoprogenitor cells that are capable of osteochondral differentiation to inform both bone repair and regeneration are a subject of intensive recent studies that have been summarized in this review. The significant contributions of these various stem cell types in bone repair and regeneration, bone defects and both restoration and regeneration of bones and cartilages as well as dentine regeneration and tooth engineering were also discussed in the current review. The strategy of stem cell regeneration will probably provide new clinical solutions and interventions for various types of bone and tooth defects/disorders. However, to apply this new strategy, further studies are still required to fully understand stem cell behavior, and regulatory mechanisms and machineries, as well as stem cell functions and mechanisms in the treatment of various types of bone/tooth defects or disorders. Understanding these functions and mechanisms may help to identify novel targets for the prevention and rescue therapy of fatal bone disease in infancy and childhood and for bone regeneration after injury. In addition, future studies on the identification of molecular programs that control osteogenic differentiation of stem cells will be crucial for developing techniques that harness the ability of these cells to regenerate diseased and damaged bones and teeth. 
Currently, there are many potential clinical studies that focus on the engineering of the entire tooth. However, the engineering of the entire tooth currently face several major challenges, including the ability to control tooth shape and size. Furthermore, the conversion of the current research approaches of stem cells identification and characterization within the dental regions into applied clinical strategies is still also a major challenge. Further studies are needed for the development of these novel approaches because they can not be easily applied clinically for various reasons such the complexity of regeneration protocols for the injured pulp. Further studies are also needed to evaluate the applications of dental progenitor stem cells and to determine whether this stem cell approach can be successfully translated into clinic. 


\section{REFERENCES}

Allen MR, Burr DB. 2007. Three years of alendronate treatment results in similar levels of vertebral microdamage as after one year of treatment. J Bone Miner Res 22 (11): 1759-65.

Arana-Chavez VE, Massa LF. 2004. Odontoblasts: the cells forming and maintaining dentine. Int J Biochem Cell Biol 36 (8): 1367-73.

Arai F, Miyamoto T, Ohneda O, et al. 1999. Commitment and differentiation of osteoclast precursor cells by the sequential expression of c-Fms and receptor activator of nuclear factor kappaB (RANK) receptors. J Exp Med 190(12): 1741-54.

Berika M, Elgayyar M and El-Hashash AH. 2014. Asymmetric cell divisions of stem cells in the lung and other systems. Front Cell Dev Biol (Stem Cell Treatments) 2:33.

Brown JP, Albert C, Nassar BA, et al. 2009. Bone turnover markers in the management of postmenopausal osteoporosis. Clin Biochem 42(10-11): 929-42.

Baxter MA, Wynn RF, Jowitt SN, Wraith J, Fairbairn LJ, Bellantuono I. 2004. Study of Telomere Length Reveals Rapid Aging of Human Marrow Stromal Cells Following in vitro Expansion. Stem Cells 22 (5): $675-682$.

Bayliss L, Mahoney DJ, Monk P. 2012. Normal bone physiology, remodelling and its hormonal regulation. Surgery 30: 47-53.

Bergman RJ, Gazit D, Kahn AJ, Gruber H, McDougall S, Hahn TJ. 1996. Age-related Changes in Osteogenic Stem Cells in Mice. J Bone Miner Res 11 (5 ):568-577.

Bernick S, Nedelman C. 1975. Effect of Aging on the Human Pulp."JOE 1 (3): 88-94. 
Black DM, Greenspan SL, Ensrud KE, et al. 2003. The effects of parathyroid hormone and alendronate alone or in combination in postmenopausal osteoporosis. N Engl J Med 349 (13): 1207-15.

Bluteau G, Luder H-U, De Bari C, Mitsiadis TA. 2008. Stem cells for tooth engineering. ECM 16:1-9.

Bone HG, Hosking D, Devogelaer JP, et al. 2004. Ten years experience with alendronate for osteoporosis in postmenopausal women. N Engl J Med 350 (12): 1189-99.

Bressan E, Botticelli D, Sivolella S, et al. 2015. Adipose-Derived Stem Cells as a Tool for Dental Implant Osseointegration: an Experimental Study in the Dog. Int J Mol Cell Med 4(4):197-208.

Brixen K, Abrahamsen B, Kassem M. 2005. Prevention and treatment of osteoporosis in women. Curr Obstet Gynaecol 15: 251-8.

Caplan AI. 2007. Adult mesenchymal stem cells for tissue engineering versus regenerative medicine. J Cell Physiol 213(2):341-7.

Chamieh F, Collignon A-M, Coyac BR, et al. 2016. Accelerated craniofacial bone regeneration through dense collagen gel scaffolds seeded with dental pulp stem cells. Scientific Reports.6:38814.

Chen W, Liu X, Chen Q, et al. 2017. Angiogenic and osteogenic regeneration in rats via calcium phosphate scaffold and endothelial cell coculture with hBMSCs, hUCMSCs, hiPSC-MSCs and hESC-MSCs. J Tissue Eng Regen Med (in press).

Chen S, Ye X, Yu X, et al. 2015. Co-culture with periodontal ligament stem cells enhanced osteoblastic differentiation of MC3T3-E1 cellsand osteoclastic differentiation of RAW264.7 cells. Int J Clin Exp Pathol 8(11):14596-607.

Cordeiro MM, Dong Z, Kaneko T, et al. 2008. Dental pulp tissue engineering with stem cells from exfoliated deciduous teeth. J Endod 34 (8): 962-9. 
Cranney A, Wells G, Willan A, et al. 2002b. Meta-analyses of therapies for postmenopausal osteoporosis. II. Meta-analysis of alendronate for the treatment of postmenopausal women. Endocr Rev 23: 508-516.

de Baat P, Heijboer MP, de Baat C. 2005. Development, physiology, and cell activity of bone. Ned Tijdschr Tandheelkd 112 (7): 258-63.

de Mendonca Costa A. et al. 2008. Reconstruction of large cranial defects in nonimmunosuppressed experimental design with human dental pulp stem cells. J Craniofac Surg 19:204-210.

D'Ippolito G, Schiller PC, Ricordi C, et al. 1999. Age-related Osteogenic Potential of Mesenchymal Stromal Stem Cells from Human Vertebral Bone Marrow. JBMR 14 (7): 1115-1122.

Dong CM, Wang XL, Wang GM, et al. 2014. A stress-induced cellular aging model with postnatal neural stem cells. Cell Death Dis 13:5;e1116.

Dougall WC, Glaccum M, Charrier K, et al. 1999. RANK is essential for osteoclast and lymph node development. Genes Dev 13(18): 2412-24.

Drake MT, Clarke BL, Khosla S. 2008. Bisphosphonates: mechanism of action and role in clinical practice. Mayo Clin Proc 83(9): 1032-45.

Duailibi MT, Duailibi SE, Young CS, et al. 2004. Bioengineered teeth from cultured rat tooth bud cells. J Dent Res 83 (7): 523-8.

Duailibi SE, Duailibi MT, Zhang W, et al. 2008. Bioengineered dental tissues grown in the rat jaw. J Dent Res 87 (8): 745-50.

Dufrane D. 2017. Impact of age on human adipose stem cells for bone tissue engineering. Cell Transplant (In Press). 
Eastell R. 2013. Identification and management of osteoporosis in older adults. Medicine 41: 47-52.

Eleftheriou KI, Rawal JS, James LE, et al. 2013. Bone structure and geometry in young men: the influence of smoking, alcohol intake and physical activity. Bone 52(1): 17-26.

Elefteriou F. 2008. Regulation of bone remodeling by the central and peripheral nervous system. Arch Biochem Biophys 473(2): 231-6.

El-Hashash, AH. 2015. Asymmetric Cell Divisions of Stem/Progenitor Cells. In: Warburton D, editor. Stem Cells, Tissue Engineering and Regenerative Medicine. London:World Scientific Publishing Co. p 21-32.

Elshahawy S, Ibrahim A, El-Hashash, AH. 2016. Behavior and asymmetric cell divisions of stem cells. In: El-Hashash AH, editor. Developmental and Stem Cell Biology in Health and Disease. Potomac, MD, USA: Bentham Science Publisher. 81-104.

Eisman JA, Bone HG, Hosking DJ, et al. 2011. Odanacatib in the treatment of postmenopausal women with low bone mineral density: Three-year continued therapy and resolution of effect. J Bone Miner Res 26 (2): $242-251$.

Edwards PC, Mason JM. 2006a. Gene-enhanced tissue engineering for dental hard tissue regeneration: (1) overview and practical considerations. Head Face Med 2: 12.

Edwards PC, Mason JM. 2006b. Gene-enhanced tissue engineering for dental hard tissue regeneration: (2) dentin-pulp and periodontal regeneration. Head Face Med 2: 16.

Ersoy FF. 2007. Osteoporosis in the elderly with chronic kidney disease. Int Urol Nephrol 39 (1): 321-31. 
Feng X, Xing J, Feng G, et al. 2014. p16 (INK4A) mediates age-related changes in mesenchymal stem cells derived from human dental pulp through the DNA damage and stress response. Mech Ageing Dev 141$142: 46-55$

Finkelstein JS, Wyland JJ, Lee H, et al. 2010. Effects of teriparatide, alendronate or both in women with postmenopausal osteoporosis. J. Clin Endocrinol Metab 95: 1838-1845.

Fitzgerald M, Chiego DJ Jr, Heys DR. 1990. Autoradiographic analysis of odontoblast replacement following pulp exposure in primate teeth. Arch Oral Biol 35(9): 707-15.

Fossett E, Khan WS, Pastides P, et al. 2012. The effects of ageing on proliferation potential, differentiation potential and cell surface characterisation of human mesenchymal stem cells. Curr Stem Cell Res Ther. $7: 282-6$.

Garnero P, Delmas PD. 2004. Bone Turnover Markers. Encyclopedia of Endocrine Dis 1: 401-13.

Gdyczynski, CM, Manbachi A, Hahemi BL, et al. 2014. On estimating the directionality distribution in pedicle trabecular bone from micro-CT images. Physiol Meas 35 (1):2415-28.

Georgi N, van Blitterswijk C, Karperien M. 2014. Mesenchymal stromal/stem cell-or chondrocyte-seeded microcarriers as building blocks for cartilage tissue engineering. Tissue Eng Part A. 20:2513-23.

Gillespie MT. 2007. Impact of cytokines and T lymphocytes upon osteoclast differentiation and function. Arthritis Res Ther 9 (2): 103.

Gothard D, Cheung K, Kanczler JM, et al. 2015. Regionally-derived cell populations and skeletal stem cells from human foetal femora exhibit specific osteochondral and multi-lineage differentiation capacity in vitroand ex vivo. Stem Cell Res Ther 6:251. 
Graham L, Cooper PR, Cassidy N, et al. 2006. The effect of calcium hydroxide on solubilisation of bioactive dentine matrix components. Biomaterials 27(14): 2865-73.

Hao P-J, Wang Z-G, Xu Q-C, et al. 2014. Effect of umbilical cord mesenchymal stem cell in peri-implant bone defect after immediate implant: an experiment study in beagle dogs. Int J Clin Exp Med 7(11):41314138.

Haschtmann D, Ferguson SJ, Stoyanov JV. 2012. BMP-2 and TGF- $\beta 3$ do not prevent spontaneous degeneration in rabbit disc explants but induce ossification of the annulus fibrosus. Eur Spine J 21:17241733.

He S, Nakada D, Morrison SJ. 2009. Mechanisms of stem cell self-renewal. Annu Rev Cell Dev Biol 25:377-406.

Horowitz MC, Lorenzo JA. 2007. B lymphocytes and the skeleton. Ann N Y Acad Sci 1117: 82-93.

Horwitz EM, Gordon PL, Koo WK, et al. 2002 .Isolated allogeneic bone marrow-derived mesenchymal cells engraft and stimulate growth in children with osteogenesis imperfecta: Implications for cell therapy of bone. Proc Natl Acad Sci USA 99(13): 8932-7.

Huang GT, Gronthos S, Shi S. 2009. Mesenchymal stem cells derived from dental tissues vs. those from other sources: their biology and role in regenerative medicine. J Dent Res 88:792-806.

Huojia M, Wu Z, Zhang X, et al. 2015. Effect of Dental Pulp Stem Cells (DPSCs) in Repairing Rabbit Alveolar Bone Defect. Clin Lab. 61(11):1703-8.

Iohara K, Murakami M, Nakata K, et al. 2014. Age-dependent decline in dental pulp regeneration after pulpectomy in dogs. Exp Gerontol 52:39-45.

Islam I, Sriram G, Li M, et al. 2016. In Vitro Osteogenic Potential of Green Fluorescent Protein Labelled Human Embryonic Stem Cell-Derived Osteoprogenitors. Stem Cells Int. 2016:1659275.

This article is protected by copyright. All rights reserved 
Joo MW, Chung SJ, Shin SH, et al. 2017. The Effect of Autologous Platelet-Rich Plasma on Bone Regeneration by Autologous Mesenchymal Stem Cells Loaded onto Allogeneic Cancellous Bone Granules. Cells Tissues Organs. (In Press).

Kartsogiannis V, Ng KW. 2004. Cell lines and primary cell cultures in the study of bone cell biology. Mol Cell Endocrinol 228(1-2): 79-102.

Kular J, Tickner J, Chim SM, et al. 2012. An overview of the regulation of bone remodeling at the cellular level. Clin Biochem 45(12): 863-73.

Lane NE, Silverman SL. Anabolic therapies. 2010. Curr Osteoporos Rep 8(1): 23-7.

Lee YH, Kim GE, Cho HJ, et al. 2013. Aging of in vitro pulp illustrates change of inflammation and dentinogenesis. J Endod 39(3):340-5.

Lee SH, Rho J, Jeong D, et al. 2006. v-ATPase V0 subunit d2-deficient mice exhibit impaired osteoclast fusion and increased bone formation. Nat Med 12(12): 1403-9.

Legrand E, Chappard D, Pascaretti C, et al. 2000. Trabecular bone microarchitecture, bone mineral density, and vertebral fractures in male osteoporosis. J Bone Miner Res 15(1): 13-9.

Li Y, He L, Pan S, et al. 2017. Three-dimensional simulated microgravity culture improves the proliferation and odontogenic differentiation of dental pulp stem cell in PLGA scaffolds implanted in mice. Mol Med Rep 15(2):873-878.

Lips P, Courpron P, Meunier PJ. 1978. Mean wall thickness of trabecular bone packets in the human iliac crest: changes with age. Calcif Tissue Res 26(1): 13-7. 
Løvschall H, Tummers M, Thesleff I, et al. 2005. Activation of the Notch signaling pathway in response to pulp capping of rat molars. Eur J Oral Sci 113(4): 312-7.

Lucaciu O, Soriţău O, Gheban D, et al. 2015. Dental follicle stem cells in bone regeneration on titanium implants. BMC Biotechnol 15:114.

Luhmann T, Germershaus O, Groll J, et al. 2012. Bone targeting for the treatment of osteoporosis. J Control Release 161(2): 198-213.

Maiti SK, Ninu AR, Sangeetha P, et al. 2016. Mesenchymal stem cells-seeded bio-ceramic construct for bone regeneration in large critical-size bone defect in rabbit. J Stem Cells Regen Med 12(2):87-99.

Marieb EN. 1998. Human Anatomy \& Physiology. (4th ed.). California: Benjamin/Cummings Science Publishing. 1072 p.

Marini F, Luzi E, Fabbri S, et al. 2015. Osteogenic differentiation of adipose tissue-derived mesenchymal stem cells on nanostructured Ti6Al4V and Ti13Nb13Zr. Clin Cases Miner Bone Metab 12(3):224-237.

Mergler S, Lobker B, Evenhuis H,et al. 2010. Feasibility of quantitative ultrasound measurement of the heel bone in people with intellectual disabilities. Res Dev Disabil 31: 1283-1290.

McClung MR, Lewiecki EM, Cohen SB, et al. 2006. Denosumab in postmenopausal women with low bone mineral density. N Engl J Med 354(8): 821-31.

Mimeault M, Batra SK. 2006. Concise review: recent advances on the significance of stem cells in tissue regeneration and cancer therapies. Stem Cells 24(11):2319-45. 
Miran S, Mitsiadis TA, Pagella P. 2016. Innovative Dental Stem Cell-Based Research. Stem Cells Int 2016: 7231038.

Morrison, S. J., Kimble, J. 2006. Asymmetric and symmetric stem-cell divisions in development and cancer. Nature 441:7097.

Mrozik K, Gronthos S, Shi S, et al. 2010. A method to isolate, purify, and characterize human periodontal ligament stem cells. Methods Mol Biol 666:269-84.

Nam Y, Rim YA, Jung SM, et al. 2017. Cord blood cell-derived iPSCs as a new candidate for chondrogenic differentiation and cartilage regeneration. Stem Cell Res \& Ther 8:16.

Nakashima M, Iohara K. 2014. Mobilized dental pulp stem cells for pulp regeneration: initiation of clinical trial. J Endod. 40 (4 Suppl): S26-32.

Neer RM, Arnaud CD, Zanchetta JR, et al. 2001. Effect of parathyroid hormone (1-34) on fractures and bone mineral density in postmenopausal women with osteoporosis. N Engl J Med 344(19): 1434-41.

Nör JE. 2006. Tooth regeneration in operative dentistry. Oper Dent 31(6): 633-42.

Ohazama A, Modino SA, Miletich I, et al. 2004. Stem-cell-based tissue engineering of murine teeth. J Dent Res 83(7): 518-22.

Olivares-Navarrete R, Hyzy SL, Hutton DL, et al. 2010. Direct and indirect effects of microstructured titanium substrates on the induction of mesenchymal stem cell differentiation towards the osteoblast lineage. Biomaterials. 31(10):2728-2735. 
Orwoll ES, Scheele WH, Paul S, et al. 2003. The effect of teriparatide [human parathyroid hormone (1-34) therapy on bone density in men with osteoporosis. J Bone Miner Res 18: 9-17.

Owston H, Giannoudis PV, Jones E. 2016. Do skeletal muscle MSCs in humans contribute to bone repair? A systematic review. Injury 47: S3-S15.

Palmqvist P, Persson E, Conaway HH, et al. 2002. IL-6, leukemia inhibitory factor, and oncostatin M stimulate bone resorption and regulate the expression of receptor activator of NF-kappa B ligand, osteoprotegerin, and receptor activator of NF-kappa B in mouse calvariae. J Immunol 169(6): 3353-62.

Parfitt AM. 2002. Targeted and nontargeted bone remodeling: relationship to basic multicellular unit origination and progression. Bone 30(1): 5-7.

Peel N. 2012. Disorders of bone metabolism. Surgery 30: 61-6.

Perry BC, Zhou D, Wu X, et al. 2008. Collection, cryopreservation, and characterization of human dental pulp-derived mesenchymal stem cells for banking and clinical use. Tissue Eng Part C Methods

14(2): 149-56.

Pierdomenico L, Bonsi L, Calvitti M, et al. 2005. Multipotent mesenchymal stem cells with immunosuppressive activity can be easily isolated from dental pulp. Transplantation 80:836-842.

Pittenger MF, Mackay AM, Beck SC, et al. 1999. Multilineage potential of adult human mesenchymal stem cells. Science 284:143-7.

Polini A, Wang J, Bai H, et al. 2014. Stable biofunctionalization of hydroxyapatite (HA) surfaces by HAbinding/osteogenic modular peptides for inducing osteogenic differentiation of mesenchymal stem cells. Biomaterials Sci. 2:1779-1786.

Qi Y, Niu L, Zhao T, et al. 2015. Combining mesenchymal stem cell sheets with platelet-rich plasma 
gel/calcium phosphate particles: a novel strategy to promote bone regeneration. Stem Cell Res Ther 6: 256.

Qi S, Yan Y, Wen Y, et al. 2017. The effect of delta-like 1 homologue on the proliferation and odontoblastic differentiation in human dental pulp stem cells. Cell Prolif. (In Press)

Qiu G, Shi Z, Xu H. et al. 2017. Bone regeneration in minipigs via calcium phosphate cement scaffold delivering autologous BMSCs and platelet-rich plasma. J Tissue Eng Regen Med (In Press).

Quarto R, Mastrogiacomo M, Cancedda R, et al. 2001. Repair of large bone defects with the use of autologous bone marrow stromal cells. N Engl J Med 344(5): 385-6.

Rachner TD, Khosla S, Hofbauer LC. 2011. Osteoporosis: now and the future. Lancet 377(9773): 1276-87.

Raggatt LJ, Partridge NC. 2010. Cellular and molecular mechanisms of bone remodeling. J Biol Chem 285 (33):25103-8.

Reppel L, Schiavi J, Charif N, et al. 2015. Chondrogenic induction of mesenchymal stromal/stem cells from Wharton's jelly embedded in alginate hydrogel and without added growth factor: an alternative stem cell source for cartilage tissue engineering. Stem Cell Res Ther 6:260.

Rombouts C, Giraud T, Jeanneau C, et al. 2017. Pulp Vascularization during Tooth Development, Regeneration, and Therapy. J Dent Res. 96 (2):137-144.

Ross SE, Hemati N, Longo KA, et al. 2000. Inhibition of Adipogenesis by Wnt Signaling. Science Signal 289 (5481): 950.

Riggs BL, Khosla S, Melton LJ III. 2002. Sex steroids and the construction and conservation of the adult skeleton. Endocr Rev 23(3): 279-302. 
Rutherford RB, Gu K. 2000. Treatment of inflamed ferret dental pulps with recombinant bone morphogenetic protein-7. Eur J Oral Sci 108(3): 202-6.

Rux DR, Wellik DM. 2017. Hox genes in the adult skeleton: Novel functions beyond embryonic development. Dev Dyn. (In Press).

Sakai K, Yamamoto A, Matsubara K, et al. 2012. Human dental pulp-derived stem cells promote locomotor recovery after complete transection of the rat spinal cord by multiple neuro-regenerative mechanisms. J Clin Invest 122:80-90.

Seo BM, Miura M, Gronthos S et al. 2004. Investigation of multipotent postnatal stem cells from human periodontal ligament. Lancet. 364(9429):149-55.

Seppänen R, Miettinen S. 2014. Bone to the chin from adipose-derived stem cells. Duodecim. 130(19):2009-16.

Sethe S, Scutt A, Stolzing A. 2006. Aging of Mesenchymal Stem Cells. Ageing Res Rev 5 (1): 91-116.

Sharpe PT. 2016. Dental mesenchymal stem. Development 143: 2273-2280.

Sloan AJ, Smith AJ. 2007. Stem cells and the dental pulp: potential roles in dentine regeneration and repair.

Oral Dis 13(2): 151-7.

Sloan AJ, Waddington RJ. 2009. Dental pulp stem cells: what, where, how? Int J Paediatr Dent 19(1): 61-70.

Smith AJ, Cassidy N, Perry H, et al. 1995. Reactionary dentinogenesis. Int J Dev Biol 39(1): 273-80.

Smith AJ, Patel M, Graham L, et al. 2005. Molecular signaling. Oral Biosci Med 2: 127-32.

Stenderup K, Justesen J, Clausen C, et al. 2003. Aging is Associated with Decreased Maximal Life Span and Accelerated Senescence of Bone Marrow Stromal Cells. Bone 33 (6): 919-926. 
Stolzing A, Coleman N, Scutt A. 2006. Glucose-Induced Replicative Senescence in Mesenchymal Stem Cells. Rejuvenation Res 9 (1): 31-35.

Szepesi Á, Matula Z, Szigeti A, et al. 2016. In Vitro Characterization of Human Mesenchymal Stem Cells Isolated from Different Tissues with a Potential to Promote Complex Bone Regeneration. Stem Cells Int 2016:3595941.

Tamaki Y, Nakahara T, Ishikawa H, et al. 2013. In vitro analysis of mesenchymal stem cells derived from human teeth and bone marrow. Odontology 101(2):121-32.

Tang Y, Tang W, Lin Y, et al. 2008. Combination of bone tissue engineering and BMP-2 gene transfection promotes bone healing in osteoporotic rats. Cell Biol Int 32(9): 1150-7.

Tang Y, Weiss SJ 2017. Snail/Slug-YAP/TAZ Complexes Cooperatively Regulate Mesenchymal Stem Cell Function and Bone Formation. Cell Cycle 16(5): 399-405.

Tang Y, Wu X, Lei W, et al. 2009. TGF-beta1-induced migration of bone mesenchymal stem cells couples bone resorption with formation. Nat Med 15(7): 757-65.

Tatsumi IS, Amizuka N, et al. 2007. Targeted ablation of osteocytes induces osteoporosis with defective mechanotransduction. Cell Metab 5(6): 464-75.

Téclès O, Laurent P, Zygouritsas S, et al. 2005. Activation of human dental pulp progenitor/stem cells in response to odontoblast injury. Arch Oral Biol 50(2): 103-8.

Tognarini I, Sorace S, Zonefrati R, et al. 2008. In vitro differentiation of human mesenchymal stem cells on Ti6Al4V surfaces. Biomaterials 29(7):809-824.

Tolar J, Teitelbaum SL, Orchard PJ. 2004. Osteopetrosis. N Engl J Med 351(27): 2839-49. 
Tritz-Schiavi J, Charif N, Henrionnet C, et al. 2010. Original approach for cartilage tissue engineering with mesenchymal stem cells. Biomed Mater Eng. 20:167-74.

Tziafas D, Kolokuris I. 1990. Inductive influences of demineralized dentin and bone matrix on pulp cells: an approach of secondary dentinogenesis. J Dent Res 69(1): 75-81.

Wang M, Li H, Si J, et al. 2017. Amniotic fluid-derived stem cells mixed with platelet rich plasma for restoration of rat alveolar bone defect Acta Biochim Biophys Sin (Shanghai) 49 (3): 197-207.

Wang Y, He T, Liu J, et al. 2016. Synergistic effects of overexpression of BMP-2 and TGF- $\beta 3$ on osteogenic differentiation of bone marrow mesenchymal stem cells. Molecular Medicine Reports, 14: 55145520.

Weatherholt AM, Fuchs RK, Warden SJ. 2012. Specialized connective tissue: bone, the structural framework of the upper extremity. J Hand Ther 25(2): 123-31.

Wu X, Pang L, Lei W, et al. 2010. Inhibition of Sca-1-positive skeletal stem cell recruitment by alendronate blunts the anabolic effects of parathyroid hormone on bone remodeling. Cell Stem Cell 7(5): 571-80.

Young CS, Terada S, Vacanti JP, et al. 2002. Tissue engineering of complex tooth structures on biodegradable polymer scaffolds. J Dent Res 81(10): 695-700.

Young CS, Abukawa H, Asrican R, et al. 2005. Tissue-engineered hybrid tooth and bone. Tissue Eng 11(910): 1599-610.

Yu J, Deng Z, Shi J, et al. 2006. Differentiation of dental pulp stem cells into regular-shaped dentin-pulp complex induced by tooth germ cell conditioned medium. Tissue Eng 12(11): 3097-105. 
Yu J, Shi J, Jin Y. 2008. Current approaches and challenges in making a bio-tooth. Tissue Eng Part B Rev 14(3): 307-19.

Yu JH, Shi JN, Deng ZH, et al. 2006. Cell pellets from dental papillae can reexhibit dental morphogenesis and dentinogenesis. Biochem Biophys Res Commun 346(1): 116-24.

Zaim M, Karaman S, Cetin G, et al. 2012. Donor age and long-term culture affect differentiation and proliferation of human bone marrow mesenchymal stem cells. Ann Hematol. 91:1175-86.

Zhai Y, Wei R, Liu J, et al. 2017. S Drug-induced premature senescence model in human dental follicle stem cells. Oncotarget. 8 (5):7276-7293.

Zhang J, Li ZG, Si YM, et al. 201. The difference on the osteogenic differentiation between periodontal ligament stem cells and bonemarrow mesenchymal stem cells under inflammatory microenviroments. Differentiation. 88(4-5):97-105. 


\section{Figure Legends}

Figure 1. Intercellular communication pathways within the Basic Multicellular Unit (BMU) that comprise the remodeling process in trabecular bone. (1) Stimulatory and inhibitory signals from osteocytes to osteoblasts (e.g. OSM, PTHrP and sclerostin). (2) Stimulatory and inhibitory signals from osteoclasts to osteoblasts (e.g. matrix-derived TGF $\beta$ and IGF-1, secreted CT-1, Sema4D and S1P). (3) Signaling within the osteoblast lineage (e.g. ephrinB2 and EphB4, Sema3a, PTHrP, OSM). (4) Stimulatory and inhibitory signals between the osteoblast and osteoclast lineages (e.g. RANKL, Sema3B, Wnt5a and OPG). (5) Marrow cell signals to osteoblasts (e.g. macrophage-derived OSM, T-cell-derived interleukins and RANKL). Hemopoietic precursors (HSC), bone mesenchymal stem cells (MSCs).

Figure 2. Stem cells for bone regeneration. Bone marrow stromal stem cells grown in a suitable extracellular medium can create a bone tissue structure. Thus, bone marrow stem cells can be grown in vitro, and cultured bone marrow osteoprogenitors can be used for regeneration of bone after seeding on an appropriate scaffold material.

Figure 3. Periodontal Ligament (PDLSC) is a source of adult stem cells that can be used for stem celldelivery therapeutics for periodontal tissue regeneration. Mesenchymal stem cells are founded in dental tissues, including periodontal ligament, dental pulp, and dental papilla. They can be isolated and grown under defined tissue culture conditions, and used in tissue engineering, including, dental tissue, nerves and bone regeneration. Delivery of periodontal ligament stem cells (PDLSCs) to periodontal intra-bony defects via periodontal ligament cell sheet transplantation is shown in this Figure. In this cell sheet method, human periodontal ligament cells are isolated from an extracted tooth (1) and cultured on temperature-responsive culture dishes at $37^{\circ} \mathrm{C}(\mathbf{2})$. Transplantable cell sheets are harvested by reducing temperature to $20^{\circ} \mathrm{C}(\mathbf{3})$, and grafted onto an athymic rat periodontitis model $24(\mathbf{4})$. 


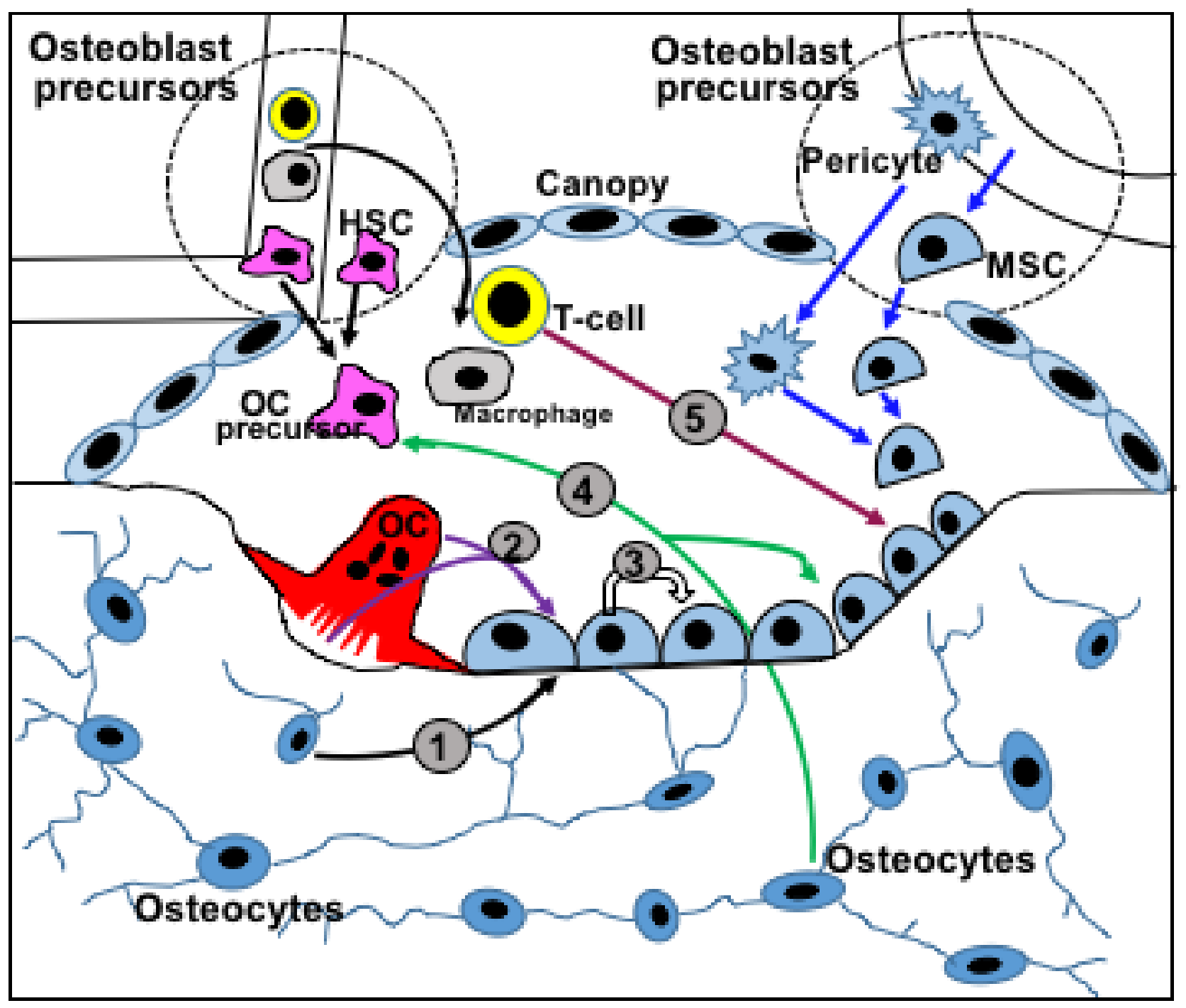

Figure-1 


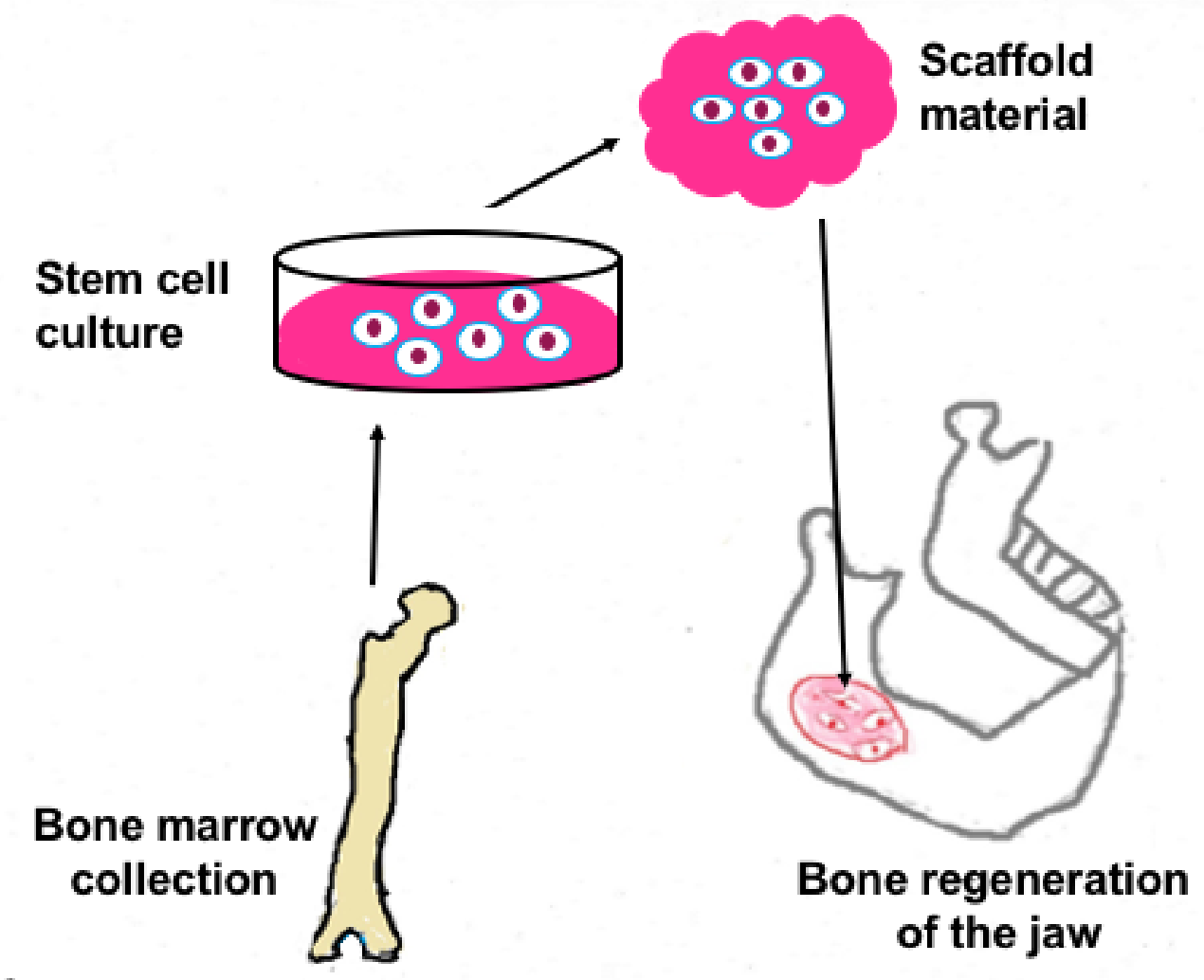

Figure-2 


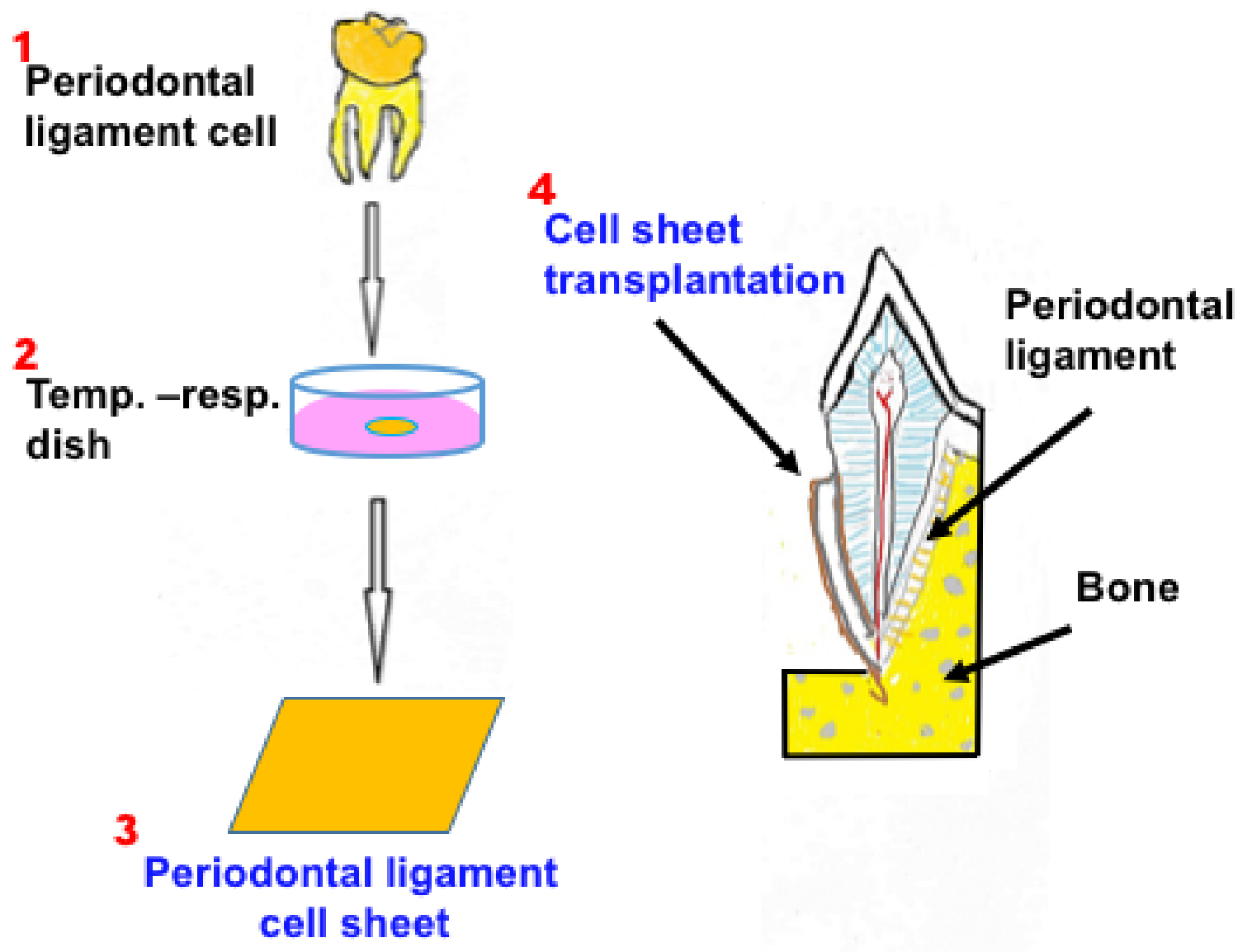

Figure-3 